\title{
Penerapan Pembelajaran Sains Berbasis Inquiry Based Learning Terintegrasi Nature of Science dalam Meningkatkan Keterampilan Metakognitif Siswa
}

\author{
Tarwiyani $^{1}$, Ibrohim ${ }^{1}$, Susriyati Mahanal ${ }^{1}$ \\ ${ }^{1}$ Pendidikan Biologi-Universitas Negeri Malang
}

\begin{tabular}{l}
\hline INFO ARTIKEL \\
\hline Riwayat Artikel: \\
Diterima: 13-05-2019 \\
Disetujui: 18-09-2019 \\
\hline
\end{tabular}

Kata kunci:

inquiry based learning;

nature of science;

metacognitive skills;

keterampilan metakognitif

\begin{abstract}
ABSTRAK
Abstract: Metacognitive skill is important to develop in students because they are role in form of students to be independent learners (self-regulated learner) as one who survives in the 21 st century. The purpose of this study was to determine the effect of application learning based Inquiry Based Learning (IBL) integrated Nature of Science (NOS) on improving students' metacognitive skills. The results of the research on the application of learning based IBL integrated NOS in experimental class proved to be able in improving the metacognitive skills of students comparing with the control class based on the significance value $\mathrm{p}(=0,000)<\alpha(0.05)$.
\end{abstract}

\begin{abstract}
Abstrak: Keterampilan metakognitif penting untuk dikembangkan pada siswa karena berperan dalam membentuk siswa menjadi pebelajar mandiri (self-regulated learner), sebagai salah satu tuntutan hidup pada abad 21. Tujuan penelitian ini adalah untuk mengetahui pengaruh penerapan pembelajaran berbasis Inquiry Based Learning (IBL) terintegrasi Nature of Science (NOS) terhadap peningkatan keterampilan metakognitif siswa. Hasil penelitian penerapan pembelajaran berbasis IBL terintegrasi NOS pada kelas eksperimen terbukti dapat meningkatkan keterampilan metakognitif siswa dibandingkan dengan kelas kontrol berdasarkan hasil uji dengan nilai signifikansi $\mathrm{p}$ $(=0,000)<\alpha(0,05)$.
\end{abstract}

\author{
Alamat Korespondensi: \\ Tarwiyani \\ Pendidikan Biologi \\ Universitas Negeri Malang \\ Jalan Semarang 5 Malang \\ E-mail: tarwiyani@ rocketmail.com
}

Pendidikan abad 21 bertujuan mempersiapkan siswa agar memiliki keterampilan abad 21 (P21, 2008). Keterampilan abad 21 dapat diperoleh dan dikembangkan melalui proses pendidikan. Dengan adanya lingkungan belajar dan kemampuan guru sebagai faktor utama, pengembangan keterampilan abad 21 dapat dilakukan dengan banyak cara (Ledward \& Hirata, 2010). Melalui proses belajar diharapkan siswa dapat memiliki pengetahuan, keterampilan berpikir, dan kecakapan hidup yang diperlukan untuk menjadi pribadi yang berkembang dan sukses (Rahayu, 2016). Pencapaian keterampilan abad 21 dapat dilakukan dengan memberdayakan metakognisi siswa (Zubaidah, 2017).

Metakognitif berkaitan dengan kesadaran mengenai proses pemikiran atau proses pembelajaran. Jika siswa menyadari apa yang dipelajari maka siswa akan terlibat dalam proses berpikir dan mampu menghubungkan dengan lebih baik antara materi lama dengan materi baru. Hal tersebut lebih memungkinkan siswa untuk mempertahankan informasi yang diperoleh melalui kegiatan belajar (Mathias, 2006). Keterampilan metakognitif merupakan keterampilan yang berperan dalam pencapaian akademik dan pembentukan sikap siswa (Ozsoy, et al., 2009). Keterampilan metakogitif dapat melatih siswa menjadi strategis dalam belajar (Coutinho, 2007). Pernyataan tersebut merupakan kondisi ideal keterampilan metakognitif yang diharapkan dapat dimiliki dan dikembangkan pada diri siswa.

Keterampilan metakognitif terdiri dari pengetahuan dan pengaturan metakognitif. Pengetahuan metakognitif, meliputi pengetahuan deklaratif, prosedural, dan kondisional, sedangkan pengaturan metakognitif terdiri dari tiga komponen utama, yaitu perencanaan (planning), pengaturan (monitoring), dan evaluasi (evaluating) (Mahdavi, 2014). Setiap komponen dari pengaturan metakognitif memiliki manfaat yang berbeda untuk siswa dalam hal belajar. Planning membantu siswa mengingat kembali pengetahuan yang diperoleh sebelumnya sehingga mempermudah dalam proses perencanaan pemahaman materi yang sedang dipelajari. Tahap monitoring mempermudah untuk memantau kemampuan siswa ketika melakukan proses belajar. Tahap evaluate berperan dalam meningkatkan hasil belajar siswa karena siswa dapat mengevaluasi dan memperbaiki kekurangan selama proses belajar (Kamid, 2013). 
Hasil penelitian Widianingsih \& Wulan (2015) menunjukkan bahwa keterampilan metakognitif siswa SMP masih cukup rendah dan perlu ditingkatkan dalam pembelajaran. Keterampilan metakognitif berpengaruh terhadap penguasaan konsep siswa. Hasil penelitian di atas sejalan dengan beberapa hasil observasi pembelajaran dan analisis kebutuhan yang telah dilakukan serta diskusi dengan guru mata pelajaran IPA. Informasi permasalahan yang diperoleh yaitu proses pembelajaran menggunakan modul yang kurang sesuai untuk mengembangkan keterampilan berpikir siswa. Modul berisikan kegiatan pembelajaran yang bersifat membuktikan suatu konsep materi yang sudah dijelaskan di dalam modul. Hal ini mengindikasikan bahwa siswa akan mengetahui konsep materi terlebih dahulu sebelum menemukannya melalui suatu percobaan. Permasalahan lainnya yaitu sebagian besar siswa tidak memahami konsep materi tetapi hanya menghapal konsep materi tersebut. Kegiatan pembelajaran tersebut tidak mendukung berkembangnya keterampilan metakognitif siswa karena kemandirian belajar siswa kurang dikembangkan apabila hanya dengan menghapalkan konsep materi.

Upaya yang dapat dilakukan untuk mengatasi permasalahan tersebut adalah dengan menerapkan pembelajaran berbasis inkuiri terintegrasi NOS. Pembelajaran berbasis inkuiri dipilih karena siswa dapat terlibat aktif selama pembelajaran (Bell, et al., 2005; Taurista, et al., 2017). Pada pembelajaran berbasis inkuiri siswa terlibat merumuskan pertanyaan, menyelidiki dengan luas, membangun pemahaman dan pengetahuan baru (Branch \& Oberg, 2004). Pembelajaran berbasis inkuiri juga melibatkan siswa dalam eksplorasi, membangun teori, dan melakukan eksperimen. Penyelidikan juga memungkinkan siswa untuk mengembangkan keterampilan dan sikap ilmiah yang diperlukan untuk meningkatkan kemampuan dalam menjelajahi fenomena dan peristiwa untuk memecahkan masalah. Dengan harapan, saat siswa belajar, siswa akan menunjukkan kemampuan yang meningkat dalam hal keterampilan yang mereka gunakan pada saat melakukan penyelidikan. Pembelajaran inkuiri dapat menghasilkan hasil belajar kognitif dan afektif yang baik, tetapi terdapat perbedaan untuk setiap level inkuiri pada hal tersebut (Eastwell, 2006).

Pembelajaran berbasis inkuiri terintegrasi Nature of Science (NOS) juga memiliki alasan yang diperkuat oleh pernyataan Chin \& Chia (2006) bahwa pembelajaran tersebut membantu siswa untuk mengembangkan pemahaman konseptual terhadap konten sains sehingga diharapkan keterampilan metakognitif siswa dapat dikembangkan karena siswa aktif berpikir ketika menemukan suatu konsep materi melalui kegiatan inkuiri. Istilah Nature of Science sering digunakan dalam merujuk isuisu, seperti apa sains, bagaimana cara kerja sains, dasar epistemologi, dan ontologi sains (Clough, 2006; Clough, 2008). Seluruh perangkat pembelajaran yang dikembangkan berbasis model inkuiri dan mengeksplisitkan aspek NOS pada tahapan pembelajaran inkuiri yang dilakukan. Berikut aspek NOS yang dieksplisitkan di dalam proses pembelajaran yang dilakukan (1) investigasi ilmiah menggunakan berbagai jenis metode; (2) pengetahuan ilmiah didasarkan pada bukti empiris; (3) pengetahuan ilmiah terbuka untuk direvisi sesuai penemuan bukti baru; (4) model sains, hukum, mekanisme, dan teori menjelaskan fenomena alam; (5) sains adalah cara untuk mengetahui; (6) pengetahuan ilmiah menganggap adanya keteraturan dan konsistensi dalam sistem alam; (7) sains merupakan upaya manusia; (8) sains dimaksudkan untuk menjawab pertanyaan tentang alam dan materil dunia (NGSS, 2011).

\section{METODE}

Penelitian ini merupakan penelitian eksperimen semu. Penelitian yang dilakukan mencakup KD 3.9 — 4.9 materi sistem pernapasan manusia, dan KD 3.10-4.10 pada materi sistem ekskresi manusia. Penerapan pembelajaran dilakukan di kelas VIII SMP Laboratoium Universitas Negeri Malang dengan menggunakan dua kelas, yaitu kelas VIIIC sebagai kelas eksperimen dan kelas VIIIG sebagai kelas kontrol menggunakan desain penelitian nonrandomized-control group pretest-postest design. Proses pembelajaran dilakukan menggunakan model inkuiri dan menggunakan LKS sebagai panduan siswa dalam melakukan percobaan/penyelidikan serta handout sebagai bahan ajar yang bertujuan untuk membantu siswa dalam memperkuat konsep materi yang telah ditemukan saat proses penyelidikan.

Proses pembelajaran dilakukan selama bulan Februari-Maret 2019 sebanyak enam kali pertemuan. Selama proses pembelajaran, dilakukan observasi terhadap pembelajaran menggunakan lembar observasi yang bertujuan untuk mengetahui tingkat keterlaksanaan proses pembelajaran yang dilakukan guru. Untuk mengetahui pengaruh pembelajaran digunakan pemberian tes berupa soal uraian sebagai pretest-posttest dan dinilai menggunakan rubrik yang telah dikembangkan. Selanjutnya, data pretest dan posttest siswa dianalisis menggunakan analisis kovarian (anakova) satu jalur dengan bantuan SPSS 23 for Windows pada taraf signifikansi 5\%. Apabila hasil analisis data dengan anakova signifikan maka dapat dinyatakan bahwa penerapan pembelajaran tersebut berpengaruh dalam meningkatkan keterampilan metakognitif siswa. Sebelum melakukan uji anakova, data diuji normalitas dengan Kolmogorov-Smirnov dan uji homogenitas dengan Levene's Tes of Equality of Errors Variances.

\section{HASIL}

Hasil yang diperoleh berupa nilai pretest dan posttest keterampilan metakognitif siswa. Sebelum dianalisis seberapa signifikan pengaruhnya dalam meningkatkan keterampilan metakognitif siswa terlebih dahulu data diuji prasyarat kemudian dilanjutkan dengan uji anakova untuk mengetahui nilai signifikan perangkat pembelajaran tersebut. Hasil uji normalitas dapat dilihat pada tabel 1 . 
Tabel 1. Hasil Uji Normalitas Data Keterampilan Metakognitif

\begin{tabular}{lcccc}
\hline \multicolumn{1}{c}{ Variabel } & Statistik & Sig (2-tailed) & Alpha & Keterangan \\
\hline Data pretest keterampilan metakognitif & 0,090 & 0,200 & 0,05 & Normal \\
Data posttest keterampilan metakognitif & 0,108 & 0,075 & 0,05 & Normal \\
\hline
\end{tabular}

Berdasarkan Tabel 1 diketahui bahwa data keterampilan metakognitif berdistribusi normal dengan nilai sig (2-tailed) atau nilai $\mathrm{p}$ data pretest yaitu $\mathrm{p}(=0,200)>\alpha(0,05)$ dan nilai posttest sebesar $\mathrm{p}(=0,200)>\alpha(0,05)$. Data dikatakan normal jika nilai absolut (p) lebih besar dari 0,05 . Uji prasyarat selanjutnya yaitu uji homogenitas, hasil uji homogenitas dapat dilihat pada tabel 2 .

Tabel 2. Hasil Uji Homogenitas Data Keterampilan Metakognitif

\begin{tabular}{lccccc}
\hline \multicolumn{1}{c}{ Variabel } & Nilai F & df & Sig. $(\mathbf{p})$ & Alpha & Keterangan \\
\hline Data pretest keterampilan metakognitif & 0,013 & 59 & 0,909 & 0,05 & Homogen \\
Data posttest keterampilan metakognitif & 3,853 & 59 & 0,054 & 0,05 & Homogen \\
\hline
\end{tabular}

Berdasarkan Tabel 2 diketahui bahwa data keterampilan metakognititf yang diperoleh homogen dengan nilai $\mathrm{p}$ pretest $\mathrm{p}$ $(=0,053)>\alpha(0,05)$ dan nilai $\mathrm{p}$ posttest yaitu $\mathrm{p}(=0,249)>\alpha(0,05)$. Uji homogenitas dilakukan dengan tujuan untuk mengetahui tingkat homogenitas data pretest dan posttest siswa. Setelah data normal dan homogen selanjutnya dilakukan uji anakova untuk mengetahui keefektifan perangkat pembelajaran dengan melihat perbedaan data kelas eksperimen dan kelas kontrol. Hasil uji anakova satu jalur dapat dilihat pada tabel 3.

Tabel 3. Uji Anakova Data Kelas Eksperimen dan Kontrol

\begin{tabular}{lccccc}
\hline Sumber Variasi (SV) & Jumlah Kuadrat & df & Rerata Kuadrat (RK) & F & Sig. (p) \\
\hline Corrected Model & $3884,543^{\mathrm{a}}$ & 2 & 1942,272 & & \\
Intercept & 4327,674 & 1 & 4327,674 & 49,855 &, 000 \\
PRETEST & 266,835 & 1 & 266,835 & 111,085 &, 000 \\
KELAS & 3830,012 & 1 & 3830,012 & 6,849 &, 011 \\
Error & 2259,567 & 58 & 38,958 & 98,311 &, 000 \\
Total & 176801,629 & 61 & & & \\
Corrected Total & 6144,110 & 60 & & & \\
\hline
\end{tabular}

Tabel 4. Ringkasan Rerata Terkoreksi Keterampilan Metakognitif Kelas Eksperimen dan Kontrol

\begin{tabular}{lllll}
\hline Kelas & Rerata Pretest & Rerata Posttest & Selisih & Rerata Terkoreksi \\
\hline Eksperimen & 30,03 & 60,72 & 30,69 & 45,37 \\
Kontrol & 35,35 & 45,32 & 9,97 & 40,33 \\
\hline
\end{tabular}

Berdasarkan uji anakova yang telah dilakukan diketahui bahwa nilai signifikansi yang diperoleh yaitu $\mathrm{p}(=0,000)>\alpha$ $(0,05)$ sehingga dapat dinyatakan bahwa terdapat perbedaan keterampilan metakognitif siswa pada kelas eksperimen dan kelas kontrol dengan pembelajaran konvensional. Hasil ini didukung oleh nilai rerata terkoreksi yang diperoleh dari kedua kelas. Kelas eksperimen memperoleh nilai rerata terkoreksi yang lebih besar yaitu 45,37 dibandingkan dengan kelas kontrol yaitu 40,33. Nilai rerata terkoreksi tersebut membuktikan bahwa kelas eksperimen nyata lebih signifikan dibandingkan kelas kontrol dalam meningkatkan keterampilan metakognitif siswa.

\section{PEMBAHASAN}

Pengaruh pembelajaran berbasis IBL terintergasi NOS dapat diketahui setelah pembelajaran selesai dilakukan. Penerapan tersebut bertujuan untuk meningkatkan keterampilan metakognitif siswa dengan melakukan proses pembelajaran berbsis inkuiri terintegrasi NOS. Keterampilan metakognitif penting untuk dikembangkan karena berperan dalam berbagai aktivitas kognitif (Howard, 2004), memegang peranan dalam kesuksesan pembelajaran (Ozsoy et al., 2009), dan berpengaruh terhadap keberhasilan akademis siswa (Coutinho, 2007).

Data keterampilan metakognitif siswa diperoleh dari hasil jawaban siswa pada tes metakognitif yang sudah dikembangkan. Berdasarkan hasil uji anakova diperoleh nilai $p=(0,000)>\alpha(0,05)$ sehingga dapat dinyatakan bahwa ada perbedaan keterampilan metakognitif antara kelas eksperimen (menggunakan pembelajaran berbasis IBL terintegrasi NOS) dengan kelas kontrol yang menggunakan pembelajaran konvensional. Keberhasilan peningkatan keterampilan metakognitif juga didukung oleh fakta-fakta pada saat proses pembelajaran. Keterampilan metakognitif yang dikembangkan selama proses pembelajaran, meliputi keterampilan perencanaan (planning), keterampilan memantau (monitoring), dan keterampilan mengevaluasi (evaluate) (Mahdavi, 2014). Berikut kegiatan pengembangan keterampilan metakognitif siswa selama proses pembelajaran. 
Keterampilan perencanaan dapat dikembangkan pada kegiatan memfokuskan pertanyaan (aspek NOS: hipotesis digunakan sebagai sebuah gagasan yang dapat menyumbangkan pengetahuan baru). Pada kegiatan ini, siswa akan memberikan jawaban sementara mengenai pertanyaan yang telah dirumuskan pada kegiatan sebelumnya. Melalui kegiatan ini keteramplan perencanaan siswa dapat dikembangkan dengan baik karena siswa dapat memikirkan bagaimana pembelajaran yang akan mereka lakukan melalui kegiatan mengamati fenomena, membuat pertanyaan serta membuat jawaban sementara. Ketika siswa membuat jawaban sementara, siswa akan memikirkan jawaban tersebut dengan berpikir dan menggunakan atau mengingat informasi berkaitan yang telah mereka ketahui untuk membuat jawaban tersebut (Shen \& Liu, 2011). Kegiatan ini efektif dalam mengembangkan keterampilan metakognitif siswa.

Keterampilan monitoring dikembangkan pada kegiatan melakukan percobaan (aspek NOS: penyelidikan sains dipandu oleh seperangkat alat untuk memastikan ketepatan pengamatan dan objektivitas temuan). Pada saat melakukan percobaan siswa dapat memantau kinerja yang dilakukan dan menyesuaikannya dengan prosedur yang ada. Pada kegitan ini siswa akan menyadari kelemahan dari kemampuan yang dimilikinya dalam melakukan percobaan. Hal tersebut didukung oleh pernyataan Garrett et al, (2007) dan Veenman et al, (2006) bahwa proses menyadari kemampuan yang dimiliki ketika belajar merupakan suatu proses metakognitif. Pada kegiatan ini keterampilan metakognitif siswa dilatih untuk menjadi pebelajar yang mandiri (Trna, et al., 2010). Keterampilan monitoring juga dikembangkan pada kegiatan menganalisis data (aspek NOS: pengetahuan sains didasarkan pada hubungan logis dan konseptual antara bukti dan penjelasan). Melalui kegiatan ini siswa akan melakukan analisis data berdasarkan bukti yang telah diperoleh selama proses penyelidikan. Kegiatan ini dilakukan berdiskusi dengan teman kelompok. Kegiatan analisis data secara tidak langsung akan mengarahkan siswa dalam menggunakan dan mengorganisir bagaimana informasi yang diperolehnya untuk dapat digunakan dalam menyelesaikan soal dan permasalahan ketika melakukan analisis data. Dengan demikian, siswa sudah melakukan proses monitoring dan pengendalian atas proses kognitif dan berpikir di dalam dirinya.

Keterampilan evaluasi dapat dikembangkan pada kegiatan membangun pengetahuan baru dan mengomunikasikannya (aspek NOS: pengetahuan sains didasarkan pada hubungan logis dan konseptual antara bukti dan penjelasan serta pengetahuan sains bersifat kumulatif dari banyak orang dan berkontribusi terhadap pengetahuan sains). Keterampilan metakognitif yang dikembangkan yaitu keterampilan evaluasi. Pada kegiatan ini siswa akan membuat kesimpulan sebagai pengetahuan baru yang telah diperoleh berdasarkan hasil penyelidikan. Ketika siswa membuat suatu kesimpulan secara tidak langsung siswa akan menggunakan data yang telah diperoleh dan memilih informasi yang tepat untuk digunakan sebagai suatu kalimat kesimpulan (Shen \& Liu, 2011). Kemudian siswa akan mengomunikasikan kesimpulan tersebut dan menyimak kesimpulan dari teman yang lainnya, pada tahap ini siswa secara tidak langsung akan melakukan proses evaluasi pada kesimpulan yang telah dibuat dengan cara membandingkan kesimpulan miliknya dengan kesimpulan temannya. Siswa melakukan evaluasi apakah terdapat kesalahan konsep dan perlu memperbaiki konsep pada kesimpulannya atau tidak. Kemampuan siswa dalam melakukan evaluasi merupakan salah satu aktivitas metakognitif (Garrett et al., 2007). Sebagian besar siswa belum mampu membuat kesimpulan berdasarkan hasil analisis data yang telah mereka temukan. Siswa cenderung membuat kesimpulan dengan konsep yang lebih umum dan mengikuti teman sehingga keterampilan siswa dalam mengevaluasi hasil belajarnya juga kurang optimal. Oleh sebab itu, sebaiknya pada pembelajaran selanjutnya siswa lebih dilatih dalam membuat kesimpulan dari hasil percobaan yang mereka peroleh sebagai hasil belajar. Agar kemampuan siswa dalam membuat suatu simpulan dapat menjadi lebih baik.

Keberhasilan peningkatan keterampilan metakognitif dengan menggunakan perangkat pembelajaran berbasis IBL terintegrasi NOS tidak terlepas dari pengaruh model pembelajaran inkuiri yang diterapkan. Keberhasilan tersebut diperkuat oleh dasar teori bahwa kelebihan pembelajaran berbasis inkuiri dapat menekankan siswa untuk terlibat aktif selama belajar (Bell et al., 2005). Hal tersbut mendorong pemikiran aktif siswa dalam proses menyelidiki dibandingkan menghapal suatu konsep (Mathias, 2006). Hal ini sejalan dengan beberapa hasil penelitian berikut yang menyatakan bahwa pembelajaran berbasis inkuiri dapat meningkatkan keterampilan metakognitif siswa (Adita \& Azizah, 2016; Irawati, et al., 2015; Linanti, et al., 2017). Keefektifan pembelajaran yang digunakan salah satunya karena diterapkan berbasis model inkuiri dan terintegrasi NOS. Dalam hal ini, siswa dilatih secara berkesinambungan belajar menemukan konsep melalui kegiatan penyelidikan menggunakan LKS kemudian didukung dengan penggunaan handout untuk menambah pengetahuan dan memeriksa kebenaran konsep mengenai materi setelah proses penemuan melalui penyelidikan.

Hasil peningkatan keterampilan metakognitif pada penelitian ini juga memengaruhi kemampuan penguasaan konsep siswa. Hal ini sesuai dengan hasil penelitian Siswati \& Corebima, (2017) bahwa siswa yang mempunyai keterampilan metakognitif yang baik dapat dengan mudah mengontrol kemampuan kognitfnya. Lebih lanjut Puspitasari, et al. (2017) menyatakan bahwa siswa yang memiliki keterampilan berpikir (metakognitif) yang baik maka kemampuan penguasaan konsep akan baik pula. Oleh sebab itu, metakognisi penting dalam pembelajaran dan merupakan prediktor kuat keberhasilan akademik siswa dan memungkinkan siswa untuk menjadi strategis ketika belajar (Coutinho, 2007). Keberhasilan pembelajaran tersebut juga tidak terlepas dari pengintegrasian terhadap aspek NOS yang dilakukan ketika proses belajar, hal ini dikarenakan Nature of Science juga mengacu pada sains sebagai cara untuk mengetahui, atau berkaitan pada nilai-nilai dan keyakinan yang melekat pada pengembangan pengetahuan sains (Lederman, et al., 2002;Lederman, et al., 2013). Pembelajaran yang diintegrasikan dengan NOS memiliki pengaruh positif dalam meningkatkan keterampilan metakognitif siswa. 


\section{SIMPULAN}

Simpulan dari penelitian ini yaitu penerapan pembelajaran berbasis Inquiry Based Learning (IBL) terintegrasi Nature of Science (NOS) berpengaruh dalam meningkatkan keterampilan metakognitif siswa. Pembelajaran berbasis Inquiry Based Learning (IBL) terintegrasi Nature of Science (NOS) diharapkan dapat dilakukan secara berkelanjutan untuk meningkatkan keterampilan metakognitif siswa dengan lebih baik. Terutama pada materi yang lebih luas lagi dan melihat keefektifan pembelajaran tersebut terhadap keterampilan lainnya. Selain itu, untuk pembelajaran selanjutnya harus lebih melatih dan mengembangkan keterampilan metakognitif siswa. Terutama mengembangkan keterampilan metakognitif dalam membuat suatu simpulan.

\section{DAFTAR RUJUKAN}

Adita, E., \& Azizah, U. (2016). Keterampilan Metakognitif Siswa melalui Model Pembelajaran Inkuiri Terbimbing pada Materi Pokok Laju Reaksi di SMAN 1 Manyar Gresik Kelas XI. UNESA Journal of Chemical Education, 5 (1), 143-151.

Bell, R.L., Smetana, L., \& Binns, I. (2005). Simplifying Inquiry Instruction for Assessing the Inquiry Level of Classroom Activities: H.W. Wilson Company

Branch, J., \& Oberg, D. (2004). Focus on Inquiry. A Teacher's Guide to Implementing Inquiry-based Learning. Canada: Alberta Learning

Branch, R. M. (2009). Instructional Design: The ADDIE Approach. London: Springer.

Chin, Christine., \& Chia, Li-Gek. (2005). Problem-Based Learning: Using III-Structured Problem in Biology Project Work. Wiley Inter Science: www.intersciencewiley.com

Clough, M. P. (2006). Learner's Responses to the Demands of Conceptual Change: Considerations for Effective Nature of Science Instruction. Science Education, 15, 463-494. DOI 10.1007/s11191-005-4846-7.

Clough, M. P. (2007). Teaching the Nature of Science to Secondary and Post-Secondary Students: Questions Rather Than Tenets. California Journal of Science Education, 8(2), 31- 40.

Clough, M.P., \& Olson, J. K. (2008). Teaching and Assesing the Nature of Science. An Introduction. Science \& Education, 17, 143-145. DOI 10.1007/s11191-007-9083-9

Coutinho, S.A. (2007). The Relationship Between Goals, Metacognition and Academic Seccess. Eduvate Northern Illinois University, 7(1), 39-47

Das, N., Amrita., \& Singh. A. (2014). Importance of Science in School Curriculum. The National Journal, 2, 15-18.

Garret, J., Alman, M., Gardner, S., \& Born, C. (2007). Assesing students' metacognition skills. American Journal of Pharmaceutical Education, 71(1), 1-7. htpps://doi.org/10.5688/aj710114

Irawati, F., Kurniawan, H.C., Primandiri, P.R., \& Santoso, A. M. (2015). Pengaruh Model Pembelajaran Inkuiri Terbimbing terhadap Keterampilan Inkuiri dan Keterampilan Metakognitif Siswa Kelas XII IPA SMAN 6 Kediri. Disajikan dalam Seminar Nasional XII (Biologi, Sains, Lingkungan, dan Pembelajarannya), Pendidikan Biologi FKIP UNS.

Kamid. (2013). Metakognisi Siswa dalam Menyelesaikan Soal Matematika: Studi Kasus pada Siswa SMP Berdasarkan Gender. Edumatica: Jurnal Pendidikan Matematika, 3(1), 64-72.

Lederman, N.G., Abd-E-K., Bell, R. L., \& Schwartz, R. (2002). View of Nature of Science Questionnaire: Towar Valid and Meaningful Assesment of Learner's Conceptions of Nature of Science. Journal of Research in Science Teaching, 39(6), 497-521.

Lederman, N. G., Lederman, J. S., \& Antink, A. (2013). Nature of Science and Scientific Inquiry as Contexts for the Learning of Science and Achievement of Scientific Literacy. International Journal of Education in Mathematics, Science and Technology, 1(3), 139-147.

Ledward, B.C., \& Hirata, D. (2011). An Overview of $21^{\text {th }}$ Century Skills. Summary of $21^{\text {th }}$ Century Skills for Students and Teachers. Pacific Policy Research Center. Honolulu: Kamehameha Scholls- Research \& Evolution.

Leedy, P. D., \& Ormord, J, E. (2005). Practical Research: Planning and Design. $9^{\text {th }}$ Edition. Upper Saddle River, New Jersey: Pearson, Merril Prentice Hall

Linanti, A.T., Anwar, Y., \& Santoso, L.M. (2017). Pengaruh Penerapan Model Pembelajaran Inkuiri Terbimbing (Guided Inquiry) terhadap Keterampilan Metakognitif Peserta Didik Kelas XI SMA Negeri 19 Palembang pada Materi Sistem Ekskresi. Prosiding Seminar Nasinal Pendidikan dengan Tema STEM untuk Pembelajaran Sains Abad 21. 23 September.

Llewellyn, D. (2013). Teaching High School Science Through Inquiry and Argumentation $2^{\text {nd }}$ Edition. California: Corwin Sage Company.

Mahdavi, M. (2014). An Overview: Metacognition in Education. International Journal of Multidisciplinary and Current Research, 2, 529-535.

Ozsoy, G. (2009). Metacognition, Study Habits and Attitudes. International Electronic Journal of Elementary Education, 2(1)

Puspitasari, D. P., Yuliati, L., \& Kusairi, S. (2014). Keterkaitan antara Pola Keterampilan Berpikir dengan Penguasaan Konsep Siswa pada Pembelajaran Strategi Metakognisi Berbantuan Thinking Map. Indonesian Journal of Applied Physics, 4(2), $142-148$. 
Rahayu, S. (2016). Menyiapkan Calon Guru Dalam Berliterasi Sains melalui Pembelajaran Berkonteks Explisit Nature of Science (NoS). Konvensi Nasional Pendidikan Indonesia (KONASPI) VIII: Universitas Negeri Malang

Shen Y-C., \& Liu, C-H. 2011. Metacognitive Skills Development: A Web-Based Approach in Higher Education. The Turkish Journal of Educational Technology, 10 (2), 140-150

Siswati, B. H., \& Corebima, A. D. (2017). Hubungan Antara Keterampilan Metakognitif dengan Hasil Belajar Siswa Berkemampuan Akademik Berbeda Pada Pembelajaran Biologi yang Menerapkan Beberapa Model Pembelajaran. Tesis tidak diterbitkan. Universitas Negeri Malang, Malang.

Taurista, K., Sari, M. S., \& Rohman, F. (2017). Developing A Learning Package Covering a Topic on Cells and Tissues Based on Guided-Inquiry Model and Integration of Local Knowledge. Jurnal Pendidikan Sains, 5(2), 32-37.

Veenman, M.V.J., Bernadette, H.A.M., \& Wolters, V.H. 2006. Metacognition and Learning: Conceptual and Methodological Considerations.Springer, 1, 3-14

Widianingsih, A.A., \& Wulan, R. (2015). Pengaruh Strategi Metakognitif terhadap Penguasaan Konsep dan Sikap Ilmiah Siswa Kelas XI dalam Pembelajaran Sistem Reproduksi Manusia. Disampaikan pada Seminar Nasional XII (Biologi, Sains, Lingkungan, dan Pembelajarannya) Pendidikan Biologi FKIP UNS.

Zubaidah, S. (2016). Keterampilan Abad Ke-21: Keterampilan yang Diajarkan Melalui Pembelajaran. Disajikan dalam Seminar Nasional Pendidikan dengan tema "Isu-isu Strategis Pembelajaran MIPA Abad 21, Program Studi Pendidikan Biologi STKIP Persada Khatulistiwa Sintang, Kalimantan Barat, 10 Desember.

http://www.researchgate.net/publication/318013627 